\title{
AN EVALUATION OF THE ANAESTHETIC TECHNIQUES USED IN AN OUTPATIENT UNIT
}

\author{
G.M. Urbach and G. Edelist
}

OUTPATIENT ANAESTHESIA PROGRAMMES are constantly increasing throughout the world. "It is not coincidental that the earliest programmes of this type were developed in countries with a national health service, where restrictions imposed by government have limited expansion of physical facilities, but where the patient had explicit rights to unlimited medical care without further expense beyond his tax burden. The overloading of hospital facilities and medical services that have resulted served to stimulate the development of new programmes of care in an effort to solve the problems that have been created by the right to unlimited care." 1 This type of pressure has induced us to start our outpatient programme and to evaluate patient acceptance of our techniques.

Our elective outpatient surgery unit (E.O.P.S.) is a self-contained unit within the hospital consisting of two fully equipped operating rooms and a six-bed recovery room. There are also change rooms for patient and physician, a waiting room for relatives and friends, and a nursing station. This facility, separate from the regular operating rooms, is efficient and removes a great deal of traffic from our main operating area. At the same time, it allows us to use all regular facilities of the hospital as back-up should any untoward occurrence require hospital admission for the patient. Patients admitted to E.O.P.S. are all A.S.A. Physical Status I or II. They have a history taken and physical examination done by their personal physician or in the general practice unit in our hospital. The record of this examination together with the results of the haemoglobin and urinalysis and any other laboratory work deemed appropriate by the physician are forwarded to the E.O.P.S., where they are filed at the nursing station for presentation to the anaesthetist on the day of operation. We provide the forms on which all this information is entered. We also require that any patient over 45 years of age must have a chest $\mathrm{X}$-ray and electrocardiogram. At the time when patients are seen by their surgeons and when the procedure is booked, they are given a detailed instruction form which includes the information that they must not eat or drink after midnight of the day before the operation and cautioning them that they must provide a responsible adult to accompany them home.

Patients are admitted post-operatively to the recovery area, which is fully equipped with oxygen, suction and monitoring facilities, and they remain in this area until they are considered ready for discharge by the recovery-room nurse. The E.O.P.S. anaesthetist is then notified and discharges the patient only after a

G.M. Urbach, M.D., F.R.C.P. (C), Assistant Professor, Department of Anaesthesia, University of Toronto; Staff Anaesthetist, Mount Sinai Hospital, Toronto.

Gerald Edelist, M.D., F.R.C.P.(C), Professor, Department of Anaesthesia, University of Toronto; Anaesthetist-in-Chief, Mount Sinai Hospital, Toronto. 
Rhomberg test is normal. The patients are cautioned not to drink alcohol until the following evening and not to drive for 24 hours. Obviously the challenge of outpatient anaesthesia is to produce a "street-fit" patient as soon as possible after the surgical procedure with as few complications as possible. To evaluate our performance we carried out the following study.

\section{METHOD}

The subjects in our study were 250 patients scheduled for dilatation and curettage or therapeutic abortions not requiring tracheal intubation and 100 patients scheduled for dental procedures, primarily extraction of multiple impacted teeth and requiring naso-tracheal intubation. A questionnaire was prepared in which the anaesthetist filled out the date, operation, anaesthetic technique and the recovery room nurse checked off any post-operative recovery room complications. The patient was given the second part of the questionnaire and a stamped addressed envelope before being discharged and was asked to answer it at home and to mail it back to the hospital. The first 250 replies received from the gynaecology patients and the first 100 replies from the dental patients were matched with the hospital part of the questionnaire. The patient questionnaire asked the following specific questions:

1. If you required another operation, would you like to have the same anaesthetic?

2. When you left the hospital, did you feel it was safe for you to go home?

3. Did you experience any of the following:

$\begin{array}{ll}\text { vomiting } & \text { headache } \\ \text { nausea } & \text { sore throat } \\ \text { dizziness } & \text { sore arm where needle was placed }\end{array}$

4. Did you have any other symptoms that you would attribute to the anaesthetic? If yes, please describe.

The anaesthetic and recovery-room questionnaire sought the following specific information:

1. Date

2. (a) Operation (b) Duration

3. Intra-operative complications (to be completed by anaesthetist) vomiting arrhythmia airway obstruction movement hypotension other

4. Post-operative complications (to be completed by recovery-room nurse) vomiting and nausea arrhythmia airway obstruction late arousal ( $\mathrm{RR}>3 \mathrm{hrs}$ ) hypotension dizziness headache other

\section{REsults}

A detailed list of the anaesthetic techniques used are given in Table I. The variety reflects the preferences of 12 different anaesthetists. The vast majority of 
TABLE I

Anaesthetic technique

\begin{tabular}{llrr}
\hline \hline & & $\#$ & $\%$ \\
\hline (1) D \& C & Thiopentone, nitrous oxide & 92 & 36.8 \\
& Thiopentone, nitrous oxide, enflurane & 87 & 34.8 \\
& Thiopentone, fentanyl, nitrous oxide & 32 & 12.8 \\
& Nitrous oxide, enflurane & 12 & 4.8 \\
& Thiopentone, nitrous oxide, halothane & 3.6 \\
& Thiopentone, fentanyl, nitrous oxide, enflurane & 7 & 2.8 \\
& Thiopentone, fentanyl, nitrous oxide, methoxyflurane & 3 & 1.2 \\
& Fentanyl, diazepam & 3 & 1.2 \\
& Thiopentone, nitrous oxide, methoxyflurane & 2 & 0.8 \\
& Innovar & 1 & 0.4 \\
& Nitrous oxide, halothane, methoxyflurane & 1 & 0.4 \\
& Thipoentone, diazepam, nitrous oxide, methoxyflurane & 1 & 0.4 \\
Relaxant & Succinylcholine & 8 & 3.2 \\
& Thiopentone, nitrous oxide, enflurane & 46 & 46.0 \\
& Thiopentone, fentanyl, nitrous oxide & 18 & 18.0 \\
& Thiopentone, fentanyl, nitrous oxide, enflurane & 13 & 13.0 \\
& Thiopentone, fentanyl, nitrous oxide, methoxyflurane & 7 & 7.0 \\
& Thiopentone, nitrous oxide, methoxyfurane & 7 & 7.0 \\
& Nitrous oxide + enflurane & 3 & 3.0 \\
& Local + fentanyl, diazepam & 2 & 2.0 \\
& Thiopentone, fentanyl, nitrous oxide, halothane & 1 & 1.0 \\
& Thiopentone, nitrous oxide, halothane & 1 & 1.0 \\
& Halothane \& nitrous oxide, enflurane & 1 & 1.0 \\
& Not entered in questionnaire & 1 & 1.0 \\
& Succinylcholine & 75 & 75.0 \\
Relaxant for & Pancuronium & 4.0 \\
intubation & Not listed & 19.0 \\
& Not required & 2.0 \\
& & 19 &
\end{tabular}

TABLE II

\begin{tabular}{|c|c|c|c|c|c|}
\hline & \multirow[b]{2}{*}{ Intra-operative complaints } & \multicolumn{2}{|c|}{ Dental } & \multicolumn{2}{|c|}{ Gynaecological } \\
\hline & & $\begin{array}{l}\text { No. of } \\
\text { patients with } \\
\text { complaints }\end{array}$ & $\begin{array}{c}\% \\
\text { Total }\end{array}$ & $\begin{array}{l}\text { No. of } \\
\text { patients with } \\
\text { complaints }\end{array}$ & $\begin{array}{c}\% \\
\text { Total }\end{array}$ \\
\hline 1 & Movement & 3 & 3 & 17 & 6.8 \\
\hline 2 & Hiccups & 0 & 0 & 4 & 1.6 \\
\hline 3 & Vomiting & 0 & 0 & 6 & 2.4 \\
\hline 4 & Airway obstruction & 0 & 0 & 6 & 1.6 \\
\hline 5 & Severe hypotension & 0 & 0 & 1 & 0.4 \\
\hline 6 & Arrhythmia & 0 & 0 & 1 & 0.4 \\
\hline 7 & Convulsion & 0 & 0 & 1 & 0.4 \\
\hline 8 & Difficult intubation & 1 & 1 & 0 & 0 \\
\hline 9 & Nose bleed (severe) & 2 & 2 & 0 & 0 \\
\hline \multirow{2}{*}{\multicolumn{2}{|c|}{$\begin{array}{l}\text { Total complaints } \\
\text { Number of patients with complaints }\end{array}$}} & 6 & & 34 & \\
\hline & & 6 & 6 & 33 & 13.2 \\
\hline
\end{tabular}

cases were managed by various combinations of thiopentone (Pentothal), nitrous oxide, oxygen, fentanyl and enflurance (Ethrane). The complications reported during operation are listed in Table II, and the post-operative complications are listed in Table III. They are divided into complications after gynaecological procedures which required no tracheal intubation and complications after dental procedures which required nasotracheal intubation. 
TABLE III

\begin{tabular}{|c|c|c|c|c|}
\hline \multirow[b]{2}{*}{$\begin{array}{l}\text { Post-operative complications } \\
\text { (recovery room) }\end{array}$} & \multicolumn{2}{|c|}{ Dental } & \multicolumn{2}{|c|}{ Gynaecological } \\
\hline & $\begin{array}{c}\text { No. of } \\
\text { complaints }\end{array}$ & $\begin{array}{c}\% \\
\text { Total }\end{array}$ & $\begin{array}{c}\text { No. of } \\
\text { complaints }\end{array}$ & $\begin{array}{c}\% \\
\text { Total }\end{array}$ \\
\hline 1 Nausea and vomiting & 17 & 17 & 27 & 10.8 \\
\hline 2 Dizziness & 46 & 46 & 88 & 35.2 \\
\hline 3 Late arousal ( $>3 \mathrm{hrs})$ & 10 & 10 & 4 & 1.6 \\
\hline 4 Headache & 8 & 8 & 17 & 6.8 \\
\hline 5 Airway obstruction & 1 & 1 & 0 & 0 \\
\hline 6 Joint pain & 1 & 1 & 0 & 0 \\
\hline 7 Hypertension & 1 & 1 & 0 & 0 \\
\hline 8 Arrhythmia (extrasystoles) & $\overline{1}$ & 1 & 0 & 0 \\
\hline 9 Hypotension & 1 & 1 & 0 & 0 \\
\hline 10 Sore throat & 1 & 1 & 0 & 0 \\
\hline *Total complaints & 87 & & 136 & \\
\hline${ }^{*}$ Number of patients with complaints & 59 & 59 & 100 & 40 \\
\hline \multicolumn{5}{|l|}{ Post-operative complications (late) } \\
\hline 1 Nausea and vomiting & 35 & 35 & 33 & 13.2 \\
\hline 2 Dizzine & 46 & 46 & 81 & 32.5 \\
\hline 3 Headacl & 26 & 26 & 42 & 16.8 \\
\hline 4 Sore arm & 23 & 23 & 82 & 32.8 \\
\hline 5 Sore throat & 69 & 69 & 14 & 5.6 \\
\hline 6 Muscle weakness or pain & 12 & 12 & 4 & 1.6 \\
\hline 7 Depressed or crying & 3 & 3 & 1 & 0.4 \\
\hline 8 Awareness & 1 & 1 & 0 & 0 \\
\hline 9 Confusion & 1 & 1 & 1 & 0.4 \\
\hline *Total complaints & 216 & & 258 & \\
\hline${ }^{*}$ Number of patients with complaints & 90 & 90 & 165 & 66.0 \\
\hline \multirow{2}{*}{$\begin{array}{l}\text { If you required another operation, } \\
\text { would you like the same anaesthetic? } \\
\text { When you left the hospital did you feel } \\
\text { it was safe for you to go home? }\end{array}$} & \multicolumn{2}{|c|}{$91 \%$ (91 patients) } & \multicolumn{2}{|c|}{$96 \%$ (240 patients) } \\
\hline & \multicolumn{2}{|l|}{ (yes) $96 \%(9$} & \multicolumn{2}{|c|}{$98.8 \%$ (247 patients) } \\
\hline
\end{tabular}

\section{Discussion}

The objectives of outpatient anaesthesia as stated by Fishburn, et $a l^{4}$ are safe technique, adequate analgesia and amnesia for induction, operation and extubation, and few anaesthesia-related side effects. One could add the need for rapid arousal. The incidence of patients with complications during operation with the techniques we used was not great, with a total of 40 (11.4 per cent) recorded. Of these, 37 were minor and easily managed. The two major ones, hypotension and convulsions, were corrected rapidly and did not require admission to hospital. The fact that the facility was within the hospital setting allowed for early consultation and management.

No life-threatening complication occurred in the immediate post-operative period. There was a very high incidence of nausea, vomiting and dizziness which, however, was comparable to the incidence of these complications in other studies ${ }^{3-5}$ and which did not appear to be related to any specific anaesthetic technique. This is one area where great improvement is possible and on which attention should be focussed. 
The techniques used were aimed at providing adequate anaesthesia, analgesia and amnesia. The problem of awareness during surgery has been discussed by others, particularly by Thompson, ${ }^{5}$ who quoted incidences of awareness from 4 to 9 per cent and Fishburn, ${ }^{4}$ who quoted an incidence of 7.7 per cent. This obviously is entirely preventable but arises from the search for a technique which provides rapid arousal. We had only one case of awareness reported, an incidence of 0.28 per cent. On the other hand, the incidence of late arousal, as defined by the inability to go home after three hours, was 1.6 per cent in the gynaecological group and 10 per cent in the dental group. This is one area where a specific agent can be implicated. Although only 14 per cent of the dental cases received methoxyflurane, 50 per cent of the late arousals had received it. This would cast doubt on its usefulness as an outpatient anaesthetic. On the other hand, enflurane was not implicated in any case of late arousal.

The size of the late arousal group of course would be affected by the discharge criteria. We felt our criteria of "street-fitness" were quite stringent, being based upon the individual's ability to converse, partake of coffee and cookies, ambulate without fear and pass a Rhomberg test. Over 96 per cent of patients felt it was safe for them to go home when they did. Therefore it is unlikely that many patients were discharged too early.

Eight of the 250 gynaecology patients received succinylcholine. Three of the eight complained bitterly of muscle aches and pains. A fourth patient described post-fasciculation pain so vividly that one would suspect that she also might have received succinylcholine, but it was not recorded.

Four of the 12 dental patients who complained of muscle pain received d-tubocurare before succinylcholine. This technique does not appear always to prevent the occurrence of pain due to succinylcholine. If possible, succinylcholine should be avoided for intubation and pancuronium substituted.

The incidence of late anaesthetic side-effects is an area of concern although it does ot differ greatly from other reported studies. Are nausea, vomiting, dizziness and headache unavoidable consequences of outpatient anaesthesia or are they preventable? There was no apparent difference between the several techniques used in respect to these sequelae.

Despite all the minor complications that we have noted, over 90 per cent of our patients stated that they would like the same anaesthetic again if they required an operation. This question was asked in an attempt to evaluate how the patient perceived the severity of the complication. We felt that if the patient did not reject the anaesthetic technique he or she probably perceived the complication as being trivial.

\section{SUMMARY}

Our follow-up of 250 gynaecology patients and 100 dental patients who had received anaesthesia for elective outpatient surgical procedures indicates:

(1) The practice of outpatient anaesthesia in proper facilities with proper selection of patients appears to be safe.

(2) There is widespread patient acceptance of surgery and anaesthesia on an outpatient basis. 
(3) Complications are frequent but minor.

(4) Many of the complications may be minimized:

(i) Adequate depth of anaesthesia preferably with a volatile agent will do away with awareness during operation.

(ii) Methoxyflurane should be avoided to minimize late arousal. Volatile agents such as enflurane or halothane would seem to be preferable to intravenous agents.

(iii) Post-fasciculation pain could be minimized by avoiding succinylcholine for short procedures like D \& $\mathrm{C}$ and using adequate depth instead. For dental procedures requiring tracheal intubation, one could perhaps use non-depolarizing muscle relaxants, like pancuronium, with reversal at the end of the procedure.

(5) Nausea, vomiting, dizziness and headache are complications that occur very frequently in all series reported and this is an area where more research is indicated.

\section{RÉSUMÉ}

Les auteurs ont effectué le relevé des complications anesthésiques immédiates et tardives chez des malades non hospitalisés et soumis à une chirurgie élective, ceci dans le but d'évaluer une clinique hospitalière destinée à la chirurgie élective sur base externe. Leur étude a porté sur 250 malades soumises à une chirurgie gynécologique et sur 100 autres patients ayant subi une chirurgie dentaire. On a fait les constatations suivantes:

(1) La chirurgie des patients non hospitalisés peut se faire en toute sécurité si la sélection des cas est faite de façon judicieuse.

(2) Les malades acceptent très volontiers la chirurgie et l'anesthésie sur base externe.

(3) Les complications sont fréquentes mais elles sont d'ordre mineur.

(4) L'on peut en éliminer plusieurs avec les précautions suivantes:

(i) Une anesthésie suffisamment profonde, préférablement au moyen d'agents volatiles, pour s'assurer de l'inconscience.

(ii) Le méthoxyflurane devrait être évité; il allonge le temps d'éveil. L'halothane et l'enflurane semblent préférables aux agents intraveineux.

(iii) Pour minimiser les douleurs post-fasciculations, il vaut mieux maintenir les malades à une profondeur d'anesthésie suffisante, plutôt que d'utiliser de la succinylcholine. Ceci s'applique surtout aux cas de courte durée, comme les curettages utérins. Lorsqu'il est nécessaire d'intuber les malades, par exemple en chirurgie dentaire, on pourrait utiliser un agent non dépolarisant, comme le pancuronium et renverser le bloc en fin dintervention.

(5) Les nausées, vomissements, les étourdissements et les maux de tête sont des complications très fréquentes; de la recherche dans ce domaine nous semble indiquée.

\section{ACKNOWLEDGMENTS}

The authors would like to acknowledge the expert secretarial assistance of Mrs. F. Sossin in the completion of this study. This project was supported by a grant from the Ohio Chemical Company. 


\section{REFERENCES}

1. Rosorf, B. The potential for outpatient surgery. International Anesthesiology Clinics, 14: 2 (Summer 1976).

2. Dubois, M. \& Gendes, I.C. Critical assessment of a method used for studying recovery from short-duration anaesthesia, British Journal of Anaesthesia, 45: 12, p. 1235 (Dec. 1973).

3. Brindle, G.F. \& Sliman, M. Anaesthetic complications in surgical outpatients. C.A.S.J. 22: 5 (Sept. 1975).

4. Fishbunn, Jr, J., Fulchumr, M., Jaroslav, H., \& Mercen, J. General anaesthesia for outpatient laparoscopy with an objective measure of recovery. Anaesthesia \& Analgesia, 53: 1, pp. 1-6 (Jan., Feb., 1974).

5. Thompson, G.E., Remington, J.M., Millaran, B., \& Bridenhaugh, L.O. Experiences with outpatient anaesthesia. Anesthesia \& Analgesia 52: 6, pp. 881-887 (Nov., Dec., (1973). 